\title{
Evaluation of the genotoxic effects of herbicide 2,4-D in Piaractus mesopotamicus by micronucleus test
}

\author{
Cowper, C.F.'; Jorge, M.J.; Jorge, L.C. ${ }^{1}$ \\ Instituto de Ictiología del Nordeste ${ }^{1}$. Facultad Ciencias Veterinarias; \\ Facultad Cs.Exactas ${ }^{2}$, Univ.Nacional del Nordeste, Corrientes (3400), Argentina. \\ E-mail: francisco_cowpercoles@hotmail.com
}

\begin{abstract}
Cowper, C.F.; Jorge, M.J.; Jorge, L.C.: Evaluation of the genotoxic effects of herbicide 2,4-D in Piaractus mesopotamicus by micronucleus test. Rev. Vet. 31: 2, 165-170, 2020. The herbicide 2,4-D is currently one of the most used agrochemicals in agriculture. The fish are target of contamination, these when being in contact with toxics develop later alterations that can be studied, reason why they are used as models in the evaluation of aquatic ecosystems. There is scarce information about the effects of these pesticides in fish. Because of this, the objective of this work was to evaluate the possible impact of a contamination with 2,4-D, in sub-lethal concentrations in Piaractus mesopotamicus, through the frequency of micronuclei $(\mathrm{MN})$ and alterations in the shape of the nuclei (NMA) in peripheral blood ery throcytes in chronic conditions (70 days). Two trials were conducted, one with the herbicide 2,4-D pure (P) and another with a commercial formulation (2,4-D bitter amine) (FC). Each experience was composed of five aquariums with two specimens in each, where different concentrations of the pesticide were administered ( $1 \mathrm{ppm}, 1.8 \mathrm{ppm}, 3.2 \mathrm{ppm}, 5.6 \mathrm{ppm}$ and $10 \mathrm{ppm}$ ), and in another with well water (control). A total of 4000 cells per individual were analyzed. Through the test MN and NMA the presence of diverse nuclear alterations was evidenced. The mentioned test for P and dilutions $1 \mathrm{ppm}, 1.8 \mathrm{ppm}, 3.2 \mathrm{ppm}, 5.6 \mathrm{ppm}$ of FC did not show significant differences with the control, while the concentration of $10 \mathrm{ppm}$ of FC differed statistically from its control, this could be due to additional components in FC.
\end{abstract}

Key words: Piaractus mesoptamicus, 2.4-D, mutagenicity, micronucleus and alteration in the shape of nuclei.

\begin{abstract}
Resumen
Cowper, C.F.; Jorge, M.J.; Jorge, L.C.: Evaluación de los efectos genotóxicos del herbicida 2,4-D en Piaractus mesopotamicus a través del test de micronúcleos. Rev. Vet. 31: 2, 165-170, 2020. Los herbicidas estánsiendo abundantemente utilizados haciendo que los mismos no solo lleguen al organismo específico sino también contaminen el medio ambiente donde son empleados. El herbicida 2,4-D es en la actualidad uno de los agroquímicos más utilizado en la agricultura. Los peces son blanco de la contaminación, éstos al estar en contacto con tóxicos desarrollan posteriormente alteraciones que pueden ser estudiadas, por lo cual son utilizados como modelos en la evaluacion de ecosistemas acuáticos. Existe escasa información acerca de los efectos de estos pesticidas en peces, siendo el actual trabajo el primero en evaluar efectos crónicos. El objetivo de la presente investigación fue evaluar el posible impacto de una contaminación con 2,4-D en concentraciones subletales en Piaractus mesopotamicus, a través de la frecuencia de micronúcleos (MN) y de las alteraciones en la forma de los núcleos (NMA) en eritrocitos de sangre periférica en condiciones crónicas (70 días). Se realizaron dos ensayos, uno con el herbicida 2,4-D puro (P) y otro con una formulación comercial (2,4-D amina Sumargo) (FC). Cada experiencia estuvo compuesta por cinco acuarios con dos ejemplares en cada uno, donde se administraron difererentes concentraciones del plaguicida ( $1 \mathrm{ppm}, 1,8 \mathrm{ppm}, 3,2 \mathrm{ppm}, 5,6 \mathrm{ppm}$ y $10 \mathrm{ppm})$, y en otra con agua de pozo (control). Se analizó un total de 4000 células por individuo. A través del test MN y NMA se evidenció la presencia de diversas alteraciones nucleares. El mencionado test para $\mathrm{P}$ y las diluciones 1 ppm, 1,8 ppm, 3,2 ppm, 5,6 ppm de FC no mostraron diferencias significativas con el control, mientras que la concentración de $10 \mathrm{ppm}$ de FC se diferenció estadísticamente de su control. El presente trabajo aporta luz de los potenciales efectos nocivos del 2,4-D en el medio ambiente y posibilita nuevos estudios prospectivos y retrospectivos.
\end{abstract}


Palabras clave: Piaractus mesoptamicus, 2.4-D, mutagenicidad, micronucleos y alteraciones morfológicas nucleares.

\section{INTRODUCTION}

The intensification of agriculture has made crops more vulnerable to pests. Agricultural practices such as multiple crops per growing season, reduced fallow and monocultures have contributed to creating favourable conditions for the emergence of pests and to reducing natural barriers to their spread ${ }^{10}$. Ecosystem will be inevitably affected by the action of pesticides, due to their toxicity, persistence and bioaccumulation.

The herbicide 2,4-D (2,4-dichlorophenoxyacetic acid) is one of the oldest synthetic pesticides. It was released in the forties. Being currently one of the most used agrochemicals in agriculture ${ }^{19}$. It is within the group of phenoxy or phenoxyacetic or chlorophenolic herbicides. It is found within the "hormonal herbicides" because it acts similarly to the natural hormone auxin, or indol-3-acetic acid (AIA) ${ }^{3}$. 2,4-D has been classified slightly and moderately dangerous (class II and III) ${ }^{28}$.

Fish are particularly targeted for contamination, for this reason, they are used as a model for the assessment of pollution in aquatic ecosystems ${ }^{21}$. Laboratory tests with fish showed that several substances were potentially genotoxic ${ }^{17}$, while others proved harmless ${ }^{4}$.

Due to the speed, sensitivity and reliability of the technique of micronucleus and nuclear morphological alterations (MN and NMA) in peripheral blood of fish, it is intensively used for the evaluation of contaminants in aquatic environment.

For this reason, the aim of the present work was to evaluate the possible impact of a contamination with 2,4-D, in sublethal concentrations in Piaractus mesopotamicus, through the frequency of micronuclei and alterations in the shape of the nuclei in erythrocytes of peripheral blood.

\section{MATERIALS AND METHODS}

The trials were conducted with juvenile specimens of $P$. mesopotamicus commonly known as "pacu". The fish were acclimatized for 30 days prior to treatment. Two trials were conducted, one with the herbicide 2,4$\mathrm{D}$ pure $(\mathrm{P})$ and another with a commercial formulation, 2,4-D Sumargo amine (FC).

In the experiments 6 aquariums of 20 liters were used with 2 specimens in each one. The duration of the trial was 70 days. Two groups were considered (treated and control). Different concentrations (1 ppm, $1.8 \mathrm{ppm}$, $3.2 \mathrm{ppm}, 5.6 \mathrm{ppm}$ and $10 \mathrm{ppm}$ ) of the herbicide were placed in the treated group and only water from artesian wells was added in the control.

After 70 days, the animals were anesthetized with xylocaine to extract blood from the caudal vein. For the analysis of micronuclei in peripheral erythrocytes, a drop of blood was placed on a slide for smears. The smears were fixed in ethanol for 10 minutes and left to air dry at room temperature; they were then stained with $\mathbf{5 \%}$ Giemsa in Sörenson buffer ( $\mathrm{pH}$ 6.9) for 20 minutes ${ }^{26}$.

The analysis of the smears was carried out by randomly sweeping the smears to count 4000 cells per individual. The MN and NMA were classified with the suggested criteria for fishs ${ }^{5}$. The program Infostat version $2013 \mathrm{e}^{9}$ was used for statistical analysis. The data were submitted to the variance analysis and Tukey's statistical test.

\section{RESULTS}

In the 22 P. mesopotamicus specimens studied, an average of 16 erythrocytes per field was observed, with a total of 4000 cells per individual. In order to determine the frequency of micronuclei and nuclear morphological alterations, the shape and structure of the cells were taken into consideration.

The following alterations were identified: $\mathrm{MN}$ : micronuclei; BN: binuclei; LOB: nuclear lobulations (lobed nuclei and blebbed nuclei); MUN: nuclear notches (notched nuclei); VAN: vacuoles (vacuolated nuclei) (Figure 1)

In each bioassay, 8,000 cells were counted for the control group and 36,000 for the treated group, evaluating a total of 16,000 ery throcytes (controls) and 72,000

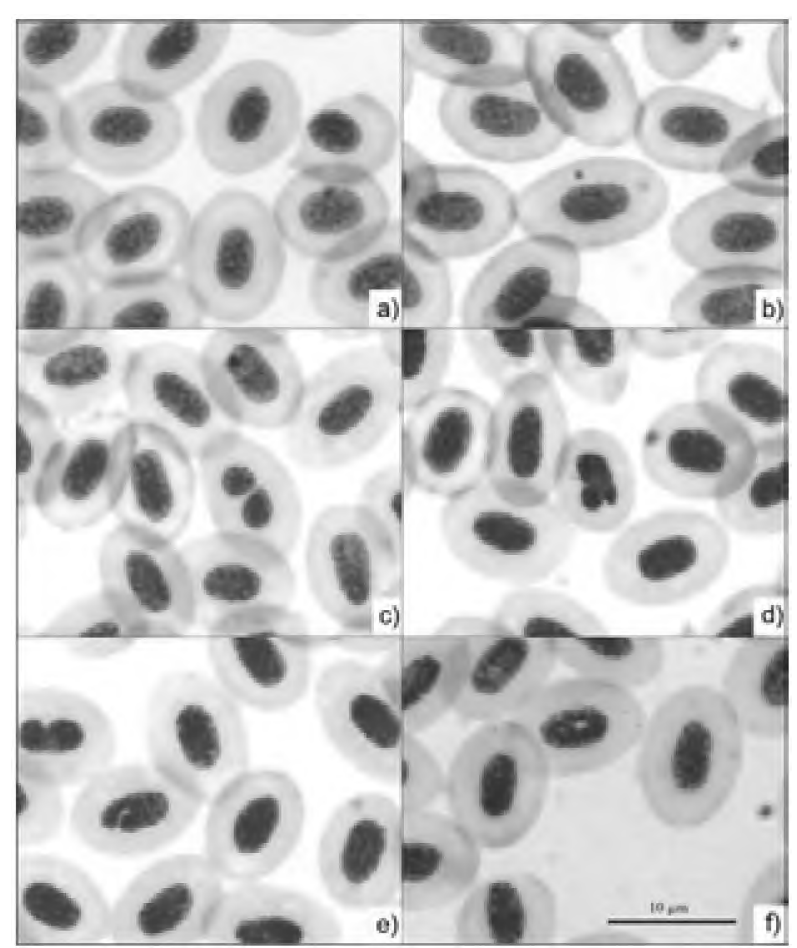

Figure 1. Erythrocytes of Piaractus mesopotamicus. a) Normal. b) Micronucleous. c) Binuclei. d) Nuclear lobulations. e) Nuclear notches. f) Vacuolated nuclei. 


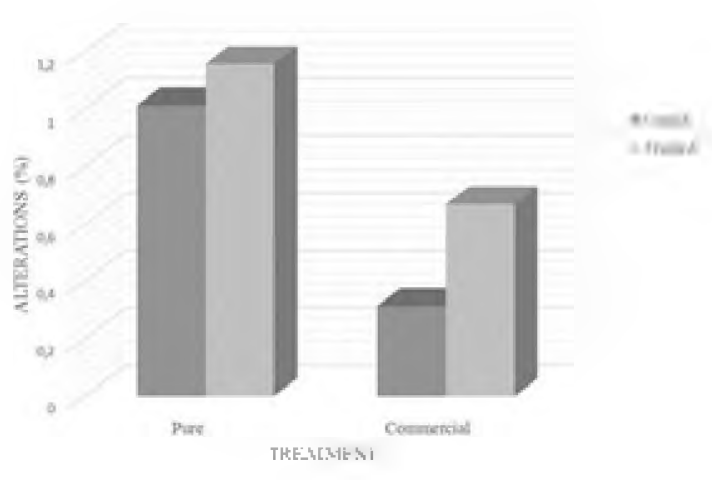

Figure 2. Alterations frequency in erythrocy tes of $P i$ aractus mesopotamicus in both assays.

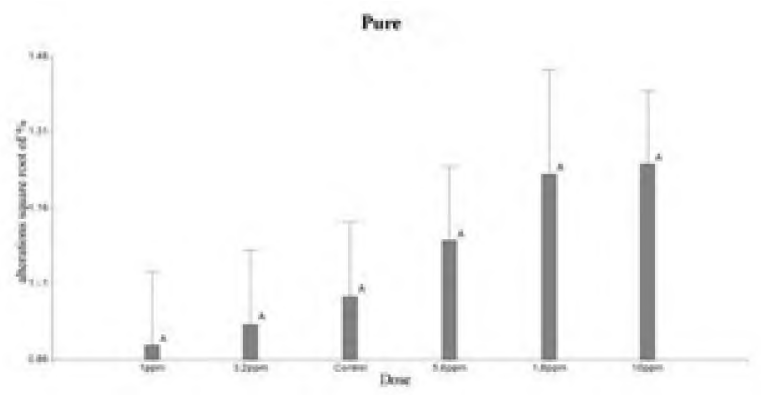

Figure 3. Alteration frequency for pure rehearsal with Tukey comparison.

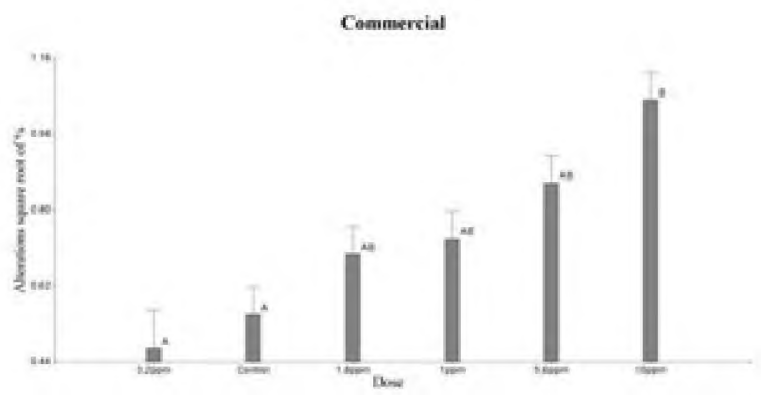

Figure 4. Alteration frequency for commercial rehearsal with Tukey comparison.

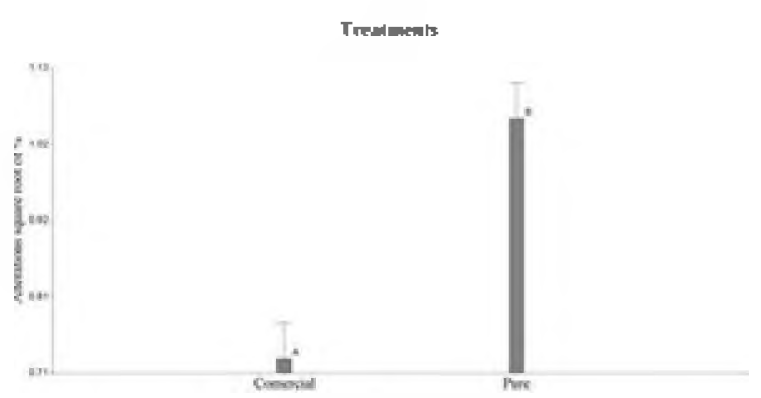

Figure 5. Alteration frequency for pure and commercial test with Tukey comparison.

(treated) for presentation (P) and (FC). In individuals exposed to the pure herbicide, $81(1 \%)$ cells with $\mathrm{MN}$ and AMN were evidenced; while in those treated, 416 $(1.15 \%)$ were identified. On the other hand, $P$. mesopotamicus specimens in contact with the commercial for-

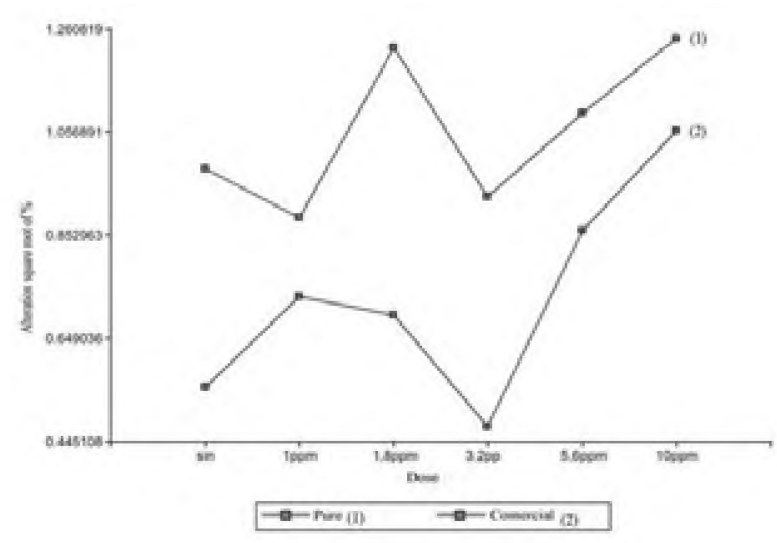

Figure 6. Dose comparison of the frequency of alterations for the pure and commercial trial.

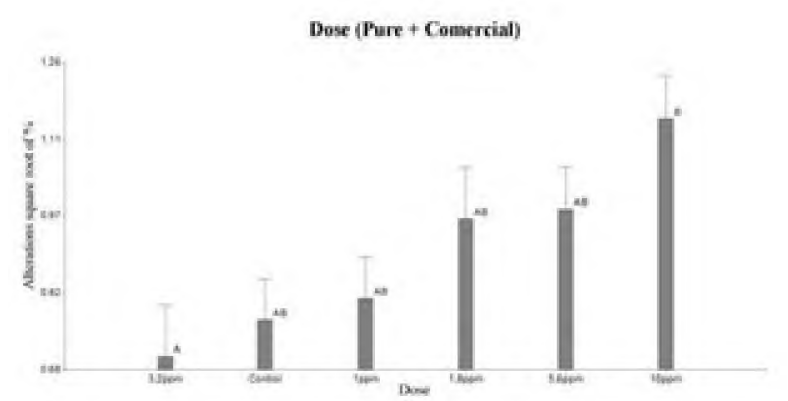

Figure 7. Tukey comparison of dose (pure + commercial) trials.

mulation showed $25(0.31 \%)$ cells with MN and NMA, and those treated showed $241(0.66 \%)$ red blood cells with abnormalities (Figure 2).

The study of the data obtained revealed that the control individuals treated with pure 2.4-D presented higher amounts of MN and NMA compared to the specimens exposed to the commercial formulation. When contrasting the control and treated group within each experience the differences are $0.15 \%$ (2.4-D pure) and $0.35 \%$ (2.4-D amine Sumagro).

Figure 3 shows that the doses used of pure 2.4-D were not statistically significant with respect to control. Whereas, in Figure 4 the 10 ppm dose of the commercial formulation was significant with the control. When comparing the 2.4-D pure and FC treatments, Tukey's test showed significant differences in the behavior of both trials (Figure 5 and Figure 6). On the other hand, comparisons according to the dose of the herbicide, did not show differences between controls and treated (Figure 7).

\section{DISCUSSION}

When comparing the data obtained in both trials, pure 2.4-D showed a higher amount of MN and AMN in the control and treated groups. This difference was probably due to the fact that both experiences were not carried out simultaneously in time. This led to the assumption that in the trial with pure 2.4-D other factors inherent to the treatment itself, such as temperature, 
oxygen level, etc, could be interacting. The impact of external factors such as temperature were demonstrated and evaluated in genotoxicity tests in fish ${ }^{18}$.

The situation in this work where only $P$. mesopotamicus specimens subjected to the $10 \mathrm{ppm}$ concentration of the herbicide 2.4-D amina Sumagro showed a significant difference with the control could be due to the fact that besides the active principle (2.4-D), these may have other compounds as by products of their industrial synthesis such as polychlorinated dibenzodioxins ${ }^{15}$, nitrosamines ${ }^{13}$ and other chlorinated phenols that may express clastogenic activity ${ }^{13}$.

On the other hand, manufactured products contain adjuvants (solvents, thinners, dispersants, emulsifiers, enhancers) in unknown proportions ${ }^{30}$. There are works in which it is evidenced that commercial formulations both in vivo and in vitro induce a greater genotoxic activity than pure drugs ${ }^{29}$.

On Oncorhynchus mykiss exposed to the commercial formulation of 2.4-D 480 for 24 and 96 hours revealed significant differences in the frequency of micronucleated erythrocytes in control and treated individuals exposed to $10 \mathrm{ppm}$ of the herbicide. No discrepancies were observed in concentrations of $2 \mathrm{ppm}$ and $20 \mathrm{ppm}$ regarding the control; although dilutions of $0.8 \mathrm{ppm}$ and $5 \mathrm{ppm}$ showed differences at $96 \mathrm{~h}$ and 24 $h$, respectively.

According to the author, this may be due to factors such as inhibition of hematopoiesis or the action of DNA repair enzymes ${ }^{20}$. In the same way, specimens of Cnesterodon decemaculatus contacted at doses 252 $\mathrm{mg} / 1,504 \mathrm{mg} / 1$ and $756 \mathrm{mg} / 1$ of the commercial formulation DMA (58.4\% 2.4D) showed at $48 \mathrm{~h}$ and $96 \mathrm{~h}$ an increase in the frequency of MN and NMA, evidencing significant effects and for the 3 doses used ${ }^{25}$.

In relation to the pure 2.4-D trial, no statistically significant differences were observed between the control and treated individuals. This differs from what was found in specimens of Clarias batrachus with the pure herbicide 2,4-D at doses of $25 \mathrm{ppm}, 50 \mathrm{ppm}$ and $75 \mathrm{ppm}$ during 48, 72 and 96 hours ${ }^{2}$. On the other hand, similar toxicity test was performed in Channa punctatus which evaluated the genotoxicity of pure 2,4-D with the same concentrations and time ${ }^{11}$.

In both studies, significant differences were observed in the amount of micronuclei and nuclear morphological alterations in the erythrocy tes of the treated individuals with respect to the controls. The data reveal the existence of a positive correlation between the amount of micronuclei and nuclear deformations depending on the time and dose used. The results of these authors showed significant differences even in the lowest dose $25 \mathrm{ppm}$, which exceeds the concentration of 10 ppm of the present work. This difference probably led to not finding significant values in our dilutions.

It should be noted that despite the similarity in concentrations and exposure times cited in Clarias batrachus ${ }^{2}$ and Channa punctata ${ }^{11}$, it was observed that the alterations differ in number, this could be due to the sensitivity of the bioindicator (species). Such an assumption leads to the consideration that the response of $P$. mesopotamicus to the herbicide may have been due to its rusticity. The way species react to different xenobiotics seems to play a fundamental role in the evaluation of contaminants.

Comparative studies of the frequency of micronuclei and nuclear abnormalities in erythrocytes in three fish species C. carpio, Astyanax eigenmanniorum and Cheirodon interruptus, from Villa Dalcar lagoon (Río Cuarto, Córdoba, Argentina) showed presence of $\mathrm{MN}$ and NMA, being more frequent in $A$. eigenmanniorum and less in C. carpio ${ }^{23}$. The sensitivity in the species could have certain relation with the rusticity of each one of them ${ }^{16}$.

Thus, it was also shown that Salmo trutta (brown trout), Salmo trutta (european eel) and Phoxinus phoxinus (european minnow) species exposed to cyclophosphamide, cadmium and colchicine for 72 hours show differences in response to genotoxic agents. In specimens of S. trutta all three chemical compounds induced MN. Phoxinus phoxinus evidenced micronuclei only at cadmium exposure. However, Anguilla anguilla did not present significantly MN in any of the treatments ${ }^{24}$.

It is known that $\mathrm{MN}$ formation occurs during cell division as a result of two events: chromosomal breakage and/or mitotic spindle dysfunction, which can lead to incomplete distribution of chromosomes in daughter cells during mitosis ${ }^{1}$. The frequency of $\mathrm{MN}$ in peripheral erythrocytes is then the result of the dynamic balance between the formation of micronucleated cells and their elimination, where a modification of the basal $\mathrm{MN}$ frequency would reveal an alteration in one or both processes ${ }^{22}$.

Entry of erythrocytes into circulating blood may be caused either by new cell production by the cephalic kidney, or under stressful conditions, by the release of cells stored in the spleen. Splenic contraction has been shown in fish in response to exercise and hypoxia ${ }^{14}$.

Elimination may be by apoptosis ${ }^{7}$ or splenic removal which has been demonstrated in mammals ${ }^{6}$, although the latter would not affect to a large extent, as the elimination mechanism involves spleen sinusoids and fish have a non-sinusal structure ${ }^{27}$. The balance between the processes that are promoting $\mathrm{MN}$ frequency may vary over time ${ }^{27}$. Previous studies have suggested that exposure to contaminants inhibits ery thropoiesis ${ }^{8}$.

Consequently, fewer erythroid cells are subjected to differentiation into potentially micronucleated and altered erythrocytes. Then the formation of $\mathrm{MN}$ and NMA decreases, leading to a change in balance. As a result, the peak of micronucleated erythrocytes is observed between 1 and 5 days after exposure to contaminants ${ }^{1,27}$. This duration is short compared to the average life span of circulating ery throcytes estimated at 51 days for Carassius auratus langsdorfii ${ }^{12}$.

Since in this work the fish remained under the exposure of the herbicide for 70 days with herbicide renewal every two days, this time allowed all circulat- 
ing erythrocytes to be under the influence of the agrochemical. Therefore, it would be expected that the presence of MN and NMA should be greater in both bioassays, however this increase was only evident in fish treated with $\mathrm{FC}$ at a dose of $10 \mathrm{ppm}$.

Therefore, the data from this experience allow us to conclude that only the juveniles of Piaractus mesopotamicus put in contact with the $10 \mathrm{ppm}$ concentration of the herbicide 2,4-D amine Sumagro showed a significant increase in the frequency of erythrocytes with micronuclei and nuclear morphological alterations with respect to the controls. The results differ from those existing in the literature, possibly due to different causes: 1) the concentrations used were higher than those of the present work; 2) the sensitivity expressed by the different species exposed to 2,4-D; and 3) exposure time to the contaminant agent and the variability in the response in acute and chronic trials.

\section{REFERENCES}

1. Alsabti K, Metcalfe CD. 1995. Fish micronuclei for assessing genotoxicity in water. Mutation Research 343: 121135 .

2. Ateeq B, Farah MA, Ali MN, Ahmad W. 2002. Induction of micronuclei and erythrocyte alterations in the catfish Clarias batrachus by 2,4-dichlorophenoxyacetic acid and butachlor. Mutat Res Genetic Tox \& Envir Mutag 518: 135-144.

3. Bejarano GF. 2004. Guía ciudadana para la aplicación del Convenio de Estocolmo. Capit. 1, "2,4,5-T": el Agente Naranja y Dow, p. 14-17.

4. Belpaeme K, Delbeke K, Zhu L, Kirsch VM. 1996. Cytogenetic studies of PCB77 on brown trout (Salmo trutta fario) using the micronucleus test and the alkaline comet assay. Mutagenesis 11: 485-492.

5. Carrasco KR, Tilbury KL, Meyers MS. 1990. Assessment of the piscine micronucleus test as an in-situ biological indicator of chemical contaminant effects. Can J Fish Aquat Sci 47: 2123-2136.

6. Cristaldi M, Ieradi LA, Udroiu I, Zilli R. 2004. Comparative evaluation of back ground micronucleus frequencies in domestic mammals. Mutation Res 559: 1-9.

7. Decordier I, Dillen L, Cundari N, Kirsch VM. 2002. Elimination of micronucleated cells by apoptosis after treatment with inhibitors of microtubules. Mutagenesis 17: 337-344.

8. Dinnen RD, Tomlinson SM, Hart D, Chopra C, Heddle JA. 1988. Application of a micronucleus assay to the peripheral blood cells of rainbow trout, Salmo gairdneri. Canad Techn Rep Fish \& Aquatic Sci 1607: 69-78.

9. Dirienzo JA et al. 2013. InfoStat, versión 2013, Grupo InfoStat, FCA, Universidad Nacional de Córdoba, Argentina.

10. FAO. 1995. Food \& Agriculture Organization. Agricultura mundial hacia el año 2010. Edit. Mundi-Prensa, Madrid, $493 \mathrm{p}$

11. Farah MA, Ateeq B, Ali MN, Ahmad W. 2003. Evaluation of genotoxicity of PCP and 2,4-D by micronucleus test in freshwater fish Channa punctatus. Ecotoxicol \& Environ Safety 54: 25-29.

12. Fischer U, Ototake M, Nakanishi T. 1998. Life span of circulating blood cells in ginbuna crucian carp (Carassius auratus langsdorfii). Fish \& Shellfish Immun 5: 339-349.

13. Ibrahim MA et al. 1991. Weight of evidence on the human carcinogenicity of 24-D. Environm Health Perspect 96: 213-222.

14. Lai JC, Kakuta I, Mok HO, Rummer JL, Randall D. 2006. Effects of moderate and substantial hypoxia on erythropoietin levels in rainbow trout kidney and spleen. JExperim Biol 209: 2734-2738.

15. Linnainmaa K. 1983. Sister chromatid exchanges among workers occupationally exposed to phenoxy acid herbicides 2,4-D and MCPA. Teratogenesis, Carcinogenesis \& Mutagenesis 3: 269-279.

16. Mancini M, Grosman F. 2008. El pejerrey de las lagunas pampeanas: análisis de casos tendientes a una gestión integral de las pesquerías, $1^{\mathrm{a}}$ ed., Edit.Univ.Nac.Río Cuarto, $446 \mathrm{p}$.

17. Minissi S, Ciccotti E, Rizzoni M. 1996. Micronucleus test in erythrocytes of Barbus plebejus (Teleostei, Pisces) from two natural environments: a bioassay for the in situ detection of mutagens in freshwater. Mutat Res 367: 245251.

18. Moraes AV, Defreitas TR, Dasilva J. 2004. Comet assay using mullet (Mugil sp.) and sea catfish (Netuma sp.) erythrocytes for the detection of genotoxic pollutants in aquatic environment. Mutat Res 560: 57-67.

19. Neumeister L. 2014. Riesgos del herbicida 2,4-D, http:// www.rapaluruguay.org/agrotoxicos/Prensa/Riesgos-delherbicida $\% 202,4 \mathrm{D}$ pdf, $31 \mathrm{p}$.

20. Palma PS. 2005. Ensayo de micronúcleo en eritrocitos de Oncorhynchus mykiss como herramienta para evaluar la exposición a pesticidas potencialmente genotóxicos en el río Traiguen. Tesis Univ Cat Temuco, Chile, $116 \mathrm{p}$.

21. Park E, Lee J, Yi A, Etoh H. 1993. Fish cell line (ULF23 HU) derived from the fin of the central Oncorhynchus mykiss suitable characteristics for clastogenicity assay. In Vitro Cell Develop Biol 25: 987-994.

22. Polard T et al. 2011. Mutagenic impact on fish of runoff events in agricultural areas in south-west France. Aquatic Toxicol 101: 126-134.

23. Pollo FE, Salas NE, Mancini MA, Martino AL. 2012. Estudio comparativo de la frecuencia de micronúcleos y anormalidades nucleares en eritrocitos de tres especies ícticas. Acta Toxicol Argent 20: 62-67.

24. Rodriguez CA, Ayllon F, Garcia VE. 2003. Micronucleus test in freshwater fish species: an evaluation of its sensitivity for application in field surveys. Ecotoxicol \& Environm Safety 56: 442-448.

25. Ruiz DC, Soloneski S, Larramendy ML. 2016. Toxic and genotoxic effects of the 2,4-dichlorophenoxyacetic acid (2,4-D)-based herbicide on the neotropical fish Cnesterodon decemmaculatus. Ecotoxicol \& Environm Safety 128: 222-229.

26. Schmid W. 1975. The micronucleus test. Mutation Res 31: 9-15. 
27. Udroiu I. 2006. The micronucleus test in piscine erythrocytes. Aquatic Toxicology 79: 201-204.

28. USEPA (United States Environ mental Protection Agency). 1974. Compendium of registered pesticides, U.S. Government Printing Office, Washington, DC.

29. Vera CJ, Soloneski S, Larramendy ML. 2013. Evaluation of the genotoxic and cytotoxic effects of glyphosate-based herbicides in the ten spotted live-bearer fish Cnesterodon decemmaculatus (Jenyns, 1842). Ecotoxicol \& Environm Safety 89: 166-173.
30. Zeljezic D, Garaj VV. 2004. Chromosomal aberrations, micronuclei and nuclear buds induced in human lymphocytes by 2,4-dichlorophenoxyacetic acid pesticide formulation. Toxicology 200: 39-47. 